\title{
Sources of value creation through private equity-backed mergers and acquisitions: The case of buy-and-build strategies
}

\author{
Mariela Borell* and Diana Heger \\ Centre for European Economic Research (ZEW), Mannheim, Germany
}

\begin{abstract}
This article documents a new value creation function of private equity investors who carry out buy-and-build strategies. Buy-and-build strategies constitute an initial acquisition of a firm, serving as a "platform", by a private equity investor and follow-on private equity-backed acquisitions ("add-ons"). The investor merges the platform and add-ons into a single entity. Additionally to the selection of well performing firms by the investors prior to the transaction, we identify value-enhancing potentials which private equity investors explore through buy-and-builds. The investors bring together platforms with lower capacity utilization and lower returns, and add-ons with higher utilization and higher returns in order to allocate resources and capacity more efficiently and to improve firms' performance. However, the buy-and-build strategies only have a positive impact on the profitability of firms with increasing industry adjusted utilization. Consequently the more efficient deployment of assets for the generation of sales drives the improved performance after buy-and-builds.
\end{abstract}

November 11, 2013

Keywords: Private Equity, Buy-and-Build

JEL Codes: G24, G34, L14

\footnotetext{
${ }^{0}$ We are grateful to Tereza Tykvová and Michael Schroeder for helpful discussions and advice. Financial support from the Deutsche Forschungsgemeinschaft (DFG, grant number TY 83/1-1) is gratefully acknowledged. All errors and omissions are the responsibility of the authors.

*Dr. Mariela Borell is at the Centre for European Economic Research (ZEW), Dept. International Finance and Financial Management, P.O.Box 103443, 68034 Mannheim, Germany, E-mail: borell@zew.de, Tel.: +49-6211235144.
} 


\section{Introduction}

In this paper, we analyze a key strategy of PE investors, the so-called buy-and-build strategy $(\mathrm{B} \& \mathrm{~B})$, which can be considered as a subsequent step of a strategic alliance. $\mathrm{B} \& \mathrm{~B}$ are transactions in which a PE investor acquires a firm serving as a "platform" for further acquisitions. The follow-on acquisitions ("add-ons") are usually facilitated by the $\mathrm{PE}$ investor as well. While PE industry participants perceive the B\&B as a key strategy for value creation (Buy and Build Monitor 2010), this kind of transactions is largely unexplored scientifically. Nikoskelainen and Wright (2007) document the importance of $\mathrm{B} \& \mathrm{~B}$ and show that acquisitions carried out during the holding period of the PE target contribute to enterprize value uplift. However, the sources of value increase remain unexplored. The main research question in this study is what the sources of value creation through B\&B executed by PE investors are.

The main contribution of this paper is that it shows how PE investors combine resources to form new entities and to increase their usage efficiency in order to create value in the new entity. This paper takes an innovative approach in looking at capital utilization which may translate in value creation and furthermore, it takes two perspectives of value creation by looking at earnings-based measures and firm growth. Although PE and M\&A individually have received much attention in the corporate finance literature, PE-backed M\&A have been almost completely neglected. We aim to close this gap by analyzing the sources of value creation through $\mathrm{B} \& \mathrm{~B}$. For this reason, we first evaluate a possible selection effect resulting from the ability of investors to cherry-pick the most promising firms. Second, we determine the consequences of $\mathrm{B} \& \mathrm{~B}$ for the participating firms and derive the basis for value added. Moreover, we address important questions about the role of financial sponsors in allocating resources efficiently among the firms involved in B\&B.

We identify a sample of 844 companies merged within a B\&B transaction between 2000 and 2008 in 15 European countries and show that companies involved in B\&B are larger, less indebted and more profitable in the year prior to the transaction than companies not involved in $\mathrm{B} \& \mathrm{~B}$. This is a confirmation of the selection ability of PE investors who are able to identify the companies with the highest performance potential (Cressy et al., 2007). 
A multivariate analysis of the impact of firm characteristics on the probability of being acquired in a $\mathrm{B} \& \mathrm{~B}$ provides a confirmation of the selection effect in $\mathrm{B} \& \mathrm{~B}$. PE investors choose more profitable firms for B\&B transactions. While profitability is important for common PE targets as well, platforms in B\&B additionally need to realize a sufficient turnover growth in order to be selected for the transaction by the investors. In contrast, add-ons are rather slowly growing firms. Thus, we find evidence that within B\&B, PE investors facilitate the acquisition of slowly growing add-ons through fast growing platforms, which can utilize the assets of the add-ons more successfully. Furthermore, it seems that PE investors prefer firms with a higher capacity utilization measured as the turnover per firm's assets.

The post-transaction analysis and panel regressions show that platforms experience an increase and add-ons experience a decrease in capacity utilization after the B\&B. This result suggests that PE investors use B\&B to allocate resources and capacity more efficiently by shifting resources from firms with excess capacity (low utilization) to firms whose capacity is near exhaustion (high utilization). However, B\&B have a positive impact on firms' profitability, and thus, B\&B possibly improve firms' value, only for platforms and add-ons with an increasing industry-adjusted utilization measured as turnover per total assets. For firms with decreasing turnover per total assets B\&B leads to performance decrease.

Specifically for target firms of PE transactions, Davis et al. (2009) find that they experience an intensification of resource reallocation and yield a substantial productivity growth. Facilitating B\&B strategies, and thus intervening in strategic decisions of the entrepreneurs, the PE investors should be able to add value to their portfolio companies. The idea of value creation through B\&B relates to the involvement of VC funds in facilitating strategic alliances, which is documented by Lindsey (2008). These alliances are shown to create real value for the portfolio firms as measured by exiting through IPOs or acquisitions. Other related studies confirm the benefits of strategic relationships in combination with block ownership (Allen and Phillips, 2000) or corporate venture capital (Gompers and Lerner, 2000).

The remainder of the paper is structured as follows. In the next section we describe the B\&B strategy. Section 3 presents a literature background and the hypothesis development. The data and descriptive analysis are presented in Section 4. The research design for the 
evaluation of the selection effect and the value creation effect is developed in Section 5 . Section 5 also presents the results for both the selection and value creation effects. The final section concludes.

\section{Description of the buy-and-build strategy}

A B\&B strategy comprises an initial purchase of a company by a PE investor who then uses it as a platform for subsequent acquisitions of companies or divisions strategically aligned with the platform company (Fabozzi, 2002). The additional acquisitions are referred to as add-on acquisitions. The investor combines the different companies into a single entity. During the holding period of several years, the PE firm tries to increase the value of the newly created group before selling it to an industrial company (trade sale), to another financial investor (secondary purchase), or via an IPO. An important feature of B\&B, which is also generally common for PE transactions, is that the platform as well as the add-on acquisitions are frequently financed with high debt (leveraged buyout transactions, LBOs). Thus, B\&B are also known as leveraged build-ups.

The PE firm chooses a platform company from which it can pursue its acquisition strategy. The platform company usually exhibits an exceptional characteristic such as a reputation for high quality (Smit, 2001). According to the Buy \& Build Monitor 2010, add-on companies are typically smaller than the platforms and have specific tangible or intangible assets (e.g., new technology, additional markets) which offer value-adding potential to the new group of companies. In most cases, the B\&B is structured as a horizontal acquisition strategy in which the platform company and the add-ons operate in the same industry. $\mathrm{B} \& \mathrm{~B}$ tend to occur in fragmented industries with no clear market leader (see, Smit, 2001). By investing in fragmented industries, PE firms are able to avoid antitrust concerns, and, additionally, maintain a plethora of potential targets at their disposal. In such cases, the $\mathrm{B} \& \mathrm{~B}$ serve as a vehicle to consolidate fragmented industries of considerable size, similar to roll-up transactions (Brown et al., 2005).

The first group of value-adding potential is related to the PE investors, who usually undertake organizational, operational and financial changes in the target companies. These changes could be a response to factors such as the constraints of high leverage, changes in 
the managers' incentives and in the way managers are compensated, monitored and advised (e.g., Kaplan 1989a, Baker and Wruck, 1989). A high level of debt allows a company to pay less in taxes by deducting interest payments and it gives managers less freedom to pursue self-enriching projects (e.g., Jensen 1989). Furthermore, the target company benefits from the know-how of the PE investor, who, in addition to offering advice well-founded by his industry experience and his network of industry contacts, takes care of issues related to financing, acquisitions, and exiting (e.g., Kaplan, 1989). The second group of sources for value adding, might be associated with the classical advantages and synergy effects from mergers and acquisitions (M\&A). The market position of the involved companies can be improved significantly; firms could benefit from knowledge and technology transfers, companies may gain access to new markets for their products, may add new products to their portfolio or new technologies to their production processes. According to Ross et al. (2002), beyond the strategic advantages and the new market power stemming from the increased company size, the sources of synergy from M\&A include cost reductions (e.g, economies of scale or scope) and tax gains (e.g, use of tax losses from net operating losses or use of free debt capacity).

\section{Related literature and hypothesis development}

$\mathrm{B} \& \mathrm{~B}$ originate a joint acquisition relationship, in which a financial buyer can provide access to capital, financial engineering and deal-making techniques. In return, the platform company, as a strategic buyer, can provide management expertise and an increased return on investment through synergies and other business arrangements involving the target. Such joint acquisitions may allow the acquiring parties to complement each other and capitalize on acquisition opportunities that neither party would be willing to pursue on its own (Rousseau, 2010). Therefore, as M\&A supported by PE investors, B\&B open valueadding potential for the participating companies, resulting from both the PE transaction (e.g., Kaplan, 1989, Guo et al., 2010) and the firms' strategic mergers (e.g., Devos et al., 2008).

Hence, we look at possible synergies generated by B\&B transactions by examining capital utilization of platform and add-ons prior and after the transaction and document differ- 
ences. Then we analyze the impact on corporate performance and determine the impact factors on earnings-based performance measures and firm growth.

\subsection{Corporate performance}

Many valuation approaches use corporate performance as a basis for determining the firm's value (e.g., Fernandez 2002). Thus, an improvement of the performance after B\&B could be used as an indicator for the value creation potential of this strategy. Corporate performance can be reflected using different measures like earnings or cash flow measures as well as firm growth.

Earlier studies provide empirical evidence on the positive impact of management and leveraged buyouts on operating performance due to improved incentives rather than layoffs or managerial exploitation of shareholders through inside information (e.g., Kaplan, 1989, Smith, 1990 and Opler, 1992). More recently, Guo et al. (2007), find only modest increases in operating and cash flow margins that are much smaller than those found in the ' 80 s and '90s data. However, Kaplan and Stroemberg (2009) argue that the empirical evidence on the significant operating improvements for LBOs should be interpreted with some caution, due to a potential selection bias.

In line with the so-called Jensen hypothesis (Jensen, 1986, 1989), Cressy et al. (2007) find that PE-backed firms perform better than non-PE-backed firms regarding the first three post-buyout years. However, the selection of ex-ante more profitable target firms plays a key role in raising performance after the transaction. Furthermore, Cressy et al. (2007) analyze the role of specialized PE firms on operating performance and find that industry specialization of investors adds additional premium to the higher performance of the PE-backed firms. As to corporate performance after M\&A, several studies use ex post accounting performance or plant-level productivity to examine potential operating improvements in the combined firms. The results are ambiguous. Ravenscraft and Scherer (1987) find little or no evidence whereas Healy et al. (1992) and Heron and Lie (2002) find that mergers induce an improvement in operating performance which results from increases in asset productivity of the merged firms relative to their industries (Healy et al., 1992). In addition to the possibility of gaining post-transaction synergies, the displacement of inefficient managers implies a positive development of operating profitability relative to 
the pre-takeover situation (Ravenscraft and Scherer, 1987). On the other hand, if mergers take place because managers pursue growth rather than profits, or because of managerial hubris and herd behavior, they can lead to decreasing efficiency and decreasing profitability (e.g., Gugler et al., 2003). In their review article, Martynova and Renneboog (2008) state that mainly authors using earnings-based performance measures tend to find a negative post-M\&A development of profitability while authors looking at cash flow measures find more positive results.

As to the pre-transaction performance of firms involved in $\mathrm{PE}$ and $\mathrm{B} \& \mathrm{~B}$ transactions, the investors might expect sufficient cash flow generation potential in the firms in order to service the additional debt from the transaction financing. Therefore, there should be a positive relationship between a firm's profitability and the probability of being involved in a transaction. While underperforming firms are more likely to be subject of a takeover bid in M\&A (Barnes, 2000), high profitability, which indicates good management and high internal cash generation potential, is a likely characteristic of an acquirer (Harford, 2005) which in the B\&B case would correspond to a platform.

Hypothesis 1a: PE firms select better performing targets for B\&B.

Hypothesis 1b: There are significant differences between the performances of platforms and add-ons prior to the transaction.

Hypothesis 1c: B\&B lead to performance improvements in the involved firms.

According to the growth-resource mismatch hypothesis of Barnes (2000), high growth and low liquidity make an attractive investment target for an acquirer who has the financial capacity to release growth potential; low growth and high liquidity make an attractive target for an acquirer looking to gain access to more financing possibilities. In both scenarios the participating firms can take advantage of the resources or the growth opportunities of the partner firm. Lehn et al. (1990) argue that growth is positively related to a firm's need for capital. Slowly growing firms may have low capital needs and hence have more capital available for acquisitions whereas firms in fast-growth industries or fast-growing firms are likely to be better able to collect the financing needed to buy industry peers.

In fast-growing industries firms may benefit as much as possible from the growth in their own industry by expanding through M\&A (Andrade and Stafford, 2004). Since PE investors initiate and execute $\mathrm{B} \& \mathrm{~B}$, they may try to select platforms and add-ons in such 
industries. At the same time, firms in mature or declining industries may want to shift their resources into growing industries and undertake diversifying $\mathrm{M} \& \mathrm{~A}$ to guarantee their long-run survival (e.g., Powell and Yawson, 2005).

Baeyens and Manigart (2006) find that PE investors select firms with substantial growth options and suggest that PE investors try to identify the most promising, growth oriented firms and use the historical growth path as a signal for future growth. Combining the evidence for PE and M\&A transactions, we define the following hypothesis.

Hypothesis 2a: Firm's growth prior to the transaction influences the probability of being a platform in a B\&B positively and the probability of being an add-on negatively.

Hypothesis 2b: B\&B improve the growth opportunities of involved firms.

\subsection{Capacity utilization}

While the relationship between capacity utilization and PE activity has not received any academic attention until now, there are many studies on the impact of capacity utilization on merger activities and its development after M\&A. Synergy gains arising from operating improvements and increase of the productive efficiency are often reasons justifying M\&A activity.

Healy et al. (1992) show that the increase in industry-adjusted operating returns after mergers is attributable to an increase in capacity utilization, measured as the asset turnover (ratio of sales to total assets) rather than an increase in operating margins. Devos et al. (2008) provide evidence that the generated gains from mergers result from an improved resource allocation rather than from reduced tax payments or increased market power of the combined firms.

According to Maksimovic and Phillips (2001), when firms purchase assets of higher productivity, the assets of the target decline and the assets of the acquirer increase in productivity. However, the authors find that the gain in assets' productivity is higher the lower the selling firm's productivity and the higher the buyer firm's productivity. These results are consistent with more skilled acquirers being able to transfer skills and to improve the assets they buy. 
Regarding the capacity utilization as a potential driving force for mergers, Jensen (1993) and Andrade and Stafford (2004) propose that most merger activity in the '70s and '80s was motivated by the need to eliminate excess capacity. In that time period, excess capacity drove industry consolidation and restructuring through M\&A. As PE investors usually implement superior governance structures in their portfolio firms, excess capacity can also be reduced after PE through consolidation or closure of marginal facilities, and after $\mathrm{B} \& \mathrm{~B}$ through removal of duplicate functions and rationalization of operations in the merged firms. Mergers may also play an "expansionary" role (Andrade and Stafford, 2004). In such cases the transactions induce an enlargement of the firm's assets. Andrade and Stafford (2004) find that during the 1990s, merger activity was more closely related to industry expansion. The authors argue that the incentives to expand are stronger in times when existing capacity is close to exhaustion.

In line with the findings of Maksimovic and Phillips (2001), we expect that B\&B transactions facilitate the redeployment of assets. However, in contrast to Maksimovic and Phillips (2001), we expect to find evidence for the resource reallocation function of the PE investors after the $\mathrm{B} \& \mathrm{~B}$ which should be visible on a deviating development of capacity utilization for platforms and add-ons.

Hypothesis 3a: There are significant differences between the capacity utilization of platforms and add-ons prior to the transaction.

Hypothesis 3b: After a B\&B, capacity utilizations of platforms and add-ons change in different directions.

\subsection{Further factors}

Analyzing the possible selection effect in $\mathrm{B} \& \mathrm{~B}$ and $\mathrm{PE}$ investments we control for some additional factors.

\section{Debt ratio}

The ratio of debt to equity or debt to assets can be used as an indicator of debt capacity. Firms with an unused debt capacity, measured by a low debt ratio, may be able to create value by using additional debt to acquire other firms (Trahan and Shawky, 1992). As such, a low debt ratio can increase the likelihood of initiating a takeover, since transaction financing will be easier. As to the targets in a transaction, on the one hand, following 
the growth-resource mismatch hypothesis of Palepu (1986), firms with growth potential constrained by financing possibilities will make an attractive target. On the other hand, low leverage signals unused debt capacity, which makes the firm attractive to a potential buyer. In line with this argumentation, Barnes (2000) finds that a low debt to assets ratio of potential target firms is a principal factor for motivating a bid.

From the viewpoint of a PE investor, targets with relatively low debt levels should be attractive. PE transactions are usually financed with a high fraction of debt, which the investors pass on to the acquired company. Therefore, firms which possess a high remaining debt capacity, will be of particular interest for PE investors (e.g., Ambrose and Winters, 1992).

Since the platform and add-on acquisitions in a B\&B, like the common PE transactions, are usually financed with a high level of debt and a sufficient free debt capacity is crucial, we expect the impact of debt on the B\&B activity to be negative. Ambrose and Winters (1992) show this effect for PE investors. The attractiveness of targets with high debt capacity is found in Trahan and Shawky (1992), Palepu (1986) and Barnes (2000). Furthermore, we expect the leverage of firms involved in B\&B to increase after the transaction (Trahan and Shawky, 1992 for M\&A). Especially the debt level of the platforms is likely to experience a stronger rise since both the debt financing of the platform and the financing of the add-ons could be passed on to the platform company .

\section{Firm size}

The M\&A literature provides also clear evidence on the positive impact of firm size on the probability of being an acquirer in $\mathrm{M} \& \mathrm{~A}$ transactions. This corresponds to the probability of being a platform in $\mathrm{B} \& \mathrm{~B}$ transactions which relates to more resources in terms of financial strength, personnel etc. (see Trahan and Shawsky, 1992). From the point of view of a PE investor, a critical minimum size of the target company is required in order to compensate the relative high transaction fix costs for small investments through the expected returns. The impact of size on the probability of being a target in M\&A is controversially presented in the literature. The likelihood of acquisition decreases with the increasing size of the takeover target due to size-related transaction costs (Palepu, 
1986). Smaller targets are also less likely to raise concerns by competition authorities (Barnes, 2000).

A positive relation between firm size and being a target may be explained by the fact that acquisitions increase managers' power by increasing the resources under their control (Jensen, 1986). This argument is undermined by the growth-maximization theory of Mueller (1972), managers tend to undertake larger investments and to grow at a faster rate than for stockholder welfare reasons. If an acquirer seeks to achieve economies of scale or market power through the acquisition, acquiring a larger firm may help to achieve these goals sooner and at a possibly lower cost than a series of small acquisitions. Evidence for the positive relation between firm size and the probability of engaging in M\&A is documented by Trahan (1993), Maksimovic and Philips (2001) and Harford (2005) . From the point of view of a PE investor, a critical minimum size of the target company is required in order to compensate the relative high transaction fix costs for small investments through the expected returns.

As we expect the PE investment criteria to dominate over the M\&A arguments, firm size should be positively related to the probability of being a PE target, as well as being a platform or an add-on in a B\&B transaction.

\section{Industry concentration}

According to $\mathrm{PE}$ and $\mathrm{B} \& \mathrm{~B}$ practitioners industry consolidation is one of the most important incentives for B\&B. Large and highly fragmented industries offer ideal conditions for B\&B. Such industries should offer the potential for investors to realize synergies and efficiencies from consolidation (Anapolsky, 1998). ${ }^{1}$

In such industries the investors consolidate several companies into a single company which has the potential to become a regional or national leader. In line with Andrade and Stafford (2004), Huyghebaert and Luypaert (2010), and Pasiouras et al. (2010) for the M\&A activity, we expect to find a negative effect of industry concentration on B\&B activity.

\section{Persistence in the transaction activity}

The literature on the existence of merger waves (e.g., Brealey and Myers, 2003), on clus-

\footnotetext{
${ }^{1}$ See also Kaplan and Strömberg (2004) for general considerations regarding VC and PE investments, and see Lindsey (2008) and Hoffmann (2008) for strategic alliances and mergers among portfolio companies.
} 
tering of M\&A activity within industries and time (e.g., Mitchell and Mulherin, 1996, Harford, 2005, Powell and Yawson, 2005) as well as on industry specialization of PE investors (Cressy et al., 2007 and Gompers et al., 2008) suggests that there could be an industry clustering in the transaction activity as well as persistence in the sectoral investment patterns in $\mathrm{B} \& \mathrm{~B}$ activity.

\section{Data and descriptive analysis}

\subsection{Data sources and sample description}

To construct a sample of B\&B transactions we use the Zephyr data base. Zephyr is a database provided by Bureau van Dijk which contains information on over 600,000 transactions - M\&A, PE and VC transactions, and IPOs - dating back to 1997. However, the coverage of transactions is more satisfying beginning with $2000 .^{2}$ In the first step, we select all transactions classified as "institutional buyout" completed between January 1, 2000 and December 31, 2008 in the "old" EU-15 countries. To this sample we add all M\&A transactions undertaken either by an acquirer whose business description includes "private equity" or by a financial sponsor with transaction financing "private equity" or "leveraged buyout". For the purposes of this study, we concentrate on deals after which the acquirer owns 50 or more percent of the target company. ${ }^{3}$ This leaves us with a total sample of 3,743 PE transactions over the period 2000 to 2008 for the EU-15. These transactions comprise the potential platform firms.

In the second step, following the definition of $\mathrm{B} \& \mathrm{~B}$, we identify the relevant sample of PEbacked M\&A transactions. For this reason, we collect all deals undertaken by companies which have been initially taken over by PE funds. Furthermore, we extract a subgroup of transactions with a final stake of more than 50 percent and deal financing titled "private

\footnotetext{
${ }^{2}$ In recent years researchers working in the field of private equity have become aware of the existence of this database (e.g., Goossens et al., 2008, Prijcker et al., 2009, Schertler and Tykvová, 2011).

${ }^{3}$ There is a large number of studies on ownership concentration, corporate governance and firm performance (e.g., Shleifer and Vishny, 1997, Holderness, 2003). Majority owners have a general interest in profit maximization and enough control over the assets of the firm and the decisions of the management to have their interests respected (Shleifer and Vishny, 1997).
} 
equity" or "leveraged buyout" and whose acquirer is an industrial company owned by a PE firm. This group of deals constitutes the sample of add-ons.

In the third step, we collect financial information for the firms involved in a transaction and for the group of control companies from Amadeus, another Bureau van Dijk data base. Amadeus includes accounting data for firms located in Europe.

Table 1 provides information on the distribution of $\mathrm{B} \& \mathrm{~B}$ transactions over time (Panel A) and their geographic composition (Panel B) for the period 2000 to 2008 in the EU-15 countries. The first panel presents the number of companies involved in B\&B transactions with respect to their function as a platform or add-on. The initial sample consists of 297 platform companies, which have acquired 547 add-on companies during the considered time period. The development of $\mathrm{B} \& \mathrm{~B}$ activity is consistent with the development of the overall PE market. The number of B\&B transactions dropped in 2001 due to the dot-com bubble burst, and increased dramatically afterwards. ${ }^{4}$ Looking at the country composition of the sample in Panel B, the United Kingdom constitutes the largest market, accounting for nearly one third of all transactions. In general, larger economies with a higher number of companies serving as targets for acquisitions tend to have more transactions. This is consistent with the results from the Silverfleet Capital's Buy \& Build Monitor, which emphasize the regional distribution of the transactions.

\subsection{Control sample}

To analyze the B\&B, we compare the platform and add-on firms not only with PE targets but also with similar firms which were not involved in a B\&B during the considered time period. The construction of a valid control group is a crucial feature due to the non-random selection of firms by PE investors. Specific selection criteria which drive the investment decision prior to the transactions may influence the development of the financial ratios after the transaction. To avoid the possible selection bias we apply a propensity score matching and identify "similar" control firms to each firm involved in a B\&B as suggested by Rosenbaum and Rubin (1983). For this reason, we first split the whole sample into subsamples for each country, industry and year. By matching buyouts to controls in the same country and industry, year by year, we mitigate the concerns that

\footnotetext{
${ }^{4}$ For a description of the PE market development, see Kaplan, 2009.
} 
a non-random country/industry/time distribution of the buyouts could affect the results. ${ }^{5}$ We apply three-to-one nearest-neighbor matching with replacement approach hence for each platform and add-on firm we identify three control firms with similar size and age in the year prior to the B\&B. Our final sample includes 844 buyouts and 2,526 control firms. 6

\subsection{Descriptive statistics}

Since B\&B are structured as PE-backed mergers and acquisitions, firms involved in B\&B transactions could have many similarities with the usual PE targets. At the same time, due to the expected strategic advantages from the merger of platform and add-ons, there might be significant differences in the selection processes and investment criteria between the usual PE transaction and the B\&B strategies. Therefore, we simultaneously analyze the sample of firms involved in a classical PE transaction and the platforms and add-ons in $\mathrm{B} \& \mathrm{~B}$.

ROA is the performance measure calculated as the ratio of earnings before interest, taxes, depreciation and amortization (EBITDA) to total assets. UTIL is a measure for the capacity utilization. Similar to Andrade and Stafford (2004), we proxy the capacity utilization rates by the ratio of turnover to total book assets. GROWTH is firm's turnover growth per annum. DEBT is the variable indicating the level of total debt to total assets. Furthermore, we control for the firm's size (SIZE), measured as the logarithm of total assets, and for the market concentration using the Herfindahl-Hirschman-Index (HHI). To take into account that PE funds are often specialized and invest in the industry in which they have already built up know-how, we also employ the logarithm of the lagged number of transactions in the respective industry and country (DEALS). In order to incorporate the unobserved heterogeneity of countries and industries, we include country and industry dummies in the regressions $\left(\overrightarrow{D_{c}}, \overrightarrow{D_{i}}\right)$.

Summary statistics and univariate analyses, which we provide in Table 2, are shown for transaction types (PE or B\&B) and firm's function in a B\&B (platform or add-on). We compare financial ratios of firms involved in a $\mathrm{B} \& \mathrm{~B}$ with those of firms not involved in a

\footnotetext{
${ }^{5}$ There is evidence that private equity funds are usually specialized investors who prefer investments in certain industries and countries over investments in others (e.g., Cressy et al., 2007).

${ }^{6}$ We use the same matching procedure as in Tykvova and Borell, 2012.
} 
$\mathrm{B} \& \mathrm{~B}$ and with the control group (Panel A). Furthermore, we show the summary statistics of firms involved in a $\mathrm{PE}$ transaction versus firms involved in a $\mathrm{B} \& \mathrm{~B}$ as a platform or an add-on (Panel B). As stated by Barnes (2000), financial ratios are well suited for firm comparisons as they allow to control for the effect of size on the financial variables. Furthermore, ratios enable the comparison between the target firm and its industry. Therefore, we focus on the analysis of financial ratios of target and control firms as well as on industry ratios measured as industry median ratios. As a ratio denominator for size adjustments we use firms' total assets.

To facilitate a comparison of the samples, B\&B firms are excluded from the samples of PE targets. While the information for firms included in the B\&B and PE samples is evaluated for the year preceding the transaction, we use median values for the considered time period for firms without transactions. We test for the equality of means (t-test allowing for unequal variances) and the equality of distributions (Wilcoxon-Mann-Whitney test) between the samples of firms. The variables are defined in the Appendix.

Panel A in Table 2 shows that firms involved in a B\&B transaction are significantly larger and have lower debt ratios and higher returns on assets at both the mean and median values in the year before the transaction compared to firms which were not involved in a B\&B transaction. These results are in line with the ability of PE investors, who are specialized investors and have a vast knowledge of the competitive environment of target companies and of the companies' strengths and weaknesses, to select potentially superior performers (Cressy et al., 2007). This confirms the possible selection bias and importance of creation of an appropriate control sample. As the control firms are matched by size with the $\mathrm{B} \& \mathrm{~B}$ firms there are no significant differences in this variable. Also the indebtedness of the firms involved in $\mathrm{B} \& \mathrm{~B}$ and the indebtedness of the control firms do not diverge. In contrast the capacity utilization and profitability of the firms in the B\&B sample is significantly higher than the respective ratios in the control sample.

Compared to "classical" PE targets B\&B firms differ in size, utilization and returns (see Panel B). While the platforms are significantly larger than the PE targets, the add-ons have the smallest size among the three groups of firms. Furthermore, the platforms show lower mean debt ratios than the PE sample, which could be explained by the free debt 
capacity required in the platforms in order to be able to absorb the additional debt from the financing of the add-on acquisitions.

Interestingly, the platforms realize the lowest and the add-ons the highest turnover per assets among the three groups of firms, which could be an indicator for the resource reallocation as an incentive for $\mathrm{B} \& \mathrm{~B}$. These results accord with the findings of Andrade and Stafford (2004) who show that acquirers in M\&A transactions have significantly lower capacity utilization than their target companies and that the purchasing firms may seek to consolidate facilities through M\&A activities. Thus, it seems that PE investors try to realize efficiency gains by reducing the excess capacity in the platform companies and by efficiently allocating resources and capacity across platforms and add-ons. Through the shift of resources between platforms and add-ons, efficiency gains could be achieved. Similar to capacity utilization, clear differences are found for profitability. While the addons realize the highest return on assets, the platforms realize the lowest profitability among the three groups of firms. The significant differences found between the profitability and productivity of platforms and add-ons provide confirmation of Hypotheses $1 \mathrm{~b}$ and $2 \mathrm{a}$ and open value-adding potentials through more effective resource allocation between the firms.

The significant difference between the performance of platforms and PE targets suggests that the acquisition of a platform firm within a $\mathrm{B} \& \mathrm{~B}$ is driven by long-term strategic goals rather than by short-term exit or return maximization efforts. These results are in contrast to the findings of Andrade and Stafford (2004), and Maksimovic and Phillips (2001) who find that the acquirers in M\&A are firms that are better performers, at least in relative terms, and also have the ability to carry out the acquisition and the operational slack to absorb the acquired targets.

\section{Empirical analysis}

There is evidence that PE investors have specific skills and large transaction experience which enable them to select target firms with certain characteristics allowing the realization of the investors' return goals. Additionally, the investors may try to increase the value of the portfolio firms during the holding period aiming to realize an exit to a higher price than the initial purchase price of the firm. To evaluate if there could be a value creation through 
PE investors or if potential improvements after B\&B simply result from the selection of better firms prior to the investment, we evaluate the transactions in two steps. The first step comprises the analysis of the selection effect before the transaction. In the second step, we evaluate the sources of value creation based on the development of the firms after the transaction.

\subsection{Selection effect}

In order to analyse the selection ability of PE investors, we first identify those characteristics which are related to a firm involved in a $\mathrm{PE}$ or $\mathrm{B} \& \mathrm{~B}$ transaction by estimating logit models separately for each transaction type and for platforms and add-ons in B\&B. Second, we compare the impact of these firm characteristics on the transactions by applying a seemingly unrelated estimation approach. The empirical model is based on models which have been estimated for M\&A and PE transactions (see, e.g., Andrade and Stafford 2004, Opler and Titman 1993).

$$
\begin{aligned}
\mathrm{P}_{j t} & =\phi_{0}+\phi_{1} \mathrm{ROA}_{j t-1}+\phi_{2} \mathrm{UTIL}_{j t-1}+\phi_{3} \mathrm{GROWTH}_{j t-1} \\
& +\phi_{4} \mathrm{DEBT}_{j t-1}+\phi_{5} \mathrm{SIZE}_{j t-1}+\phi_{6} \mathrm{HHI}_{j t-1}+\phi_{7} \mathrm{DEALS}_{j t-1} \\
& +\Phi_{8} \overrightarrow{D_{c}}+\Phi_{9} \overrightarrow{D_{i}}+\Phi_{10} \vec{D}_{t}+u_{j t-1}
\end{aligned}
$$

The dependent variables in the three logit regressions are dummy variables for the different types of events and the different functions the firms can have. First, we look at the probability of being a target of a $\mathrm{PE}$ transaction in general and then we focus on $\mathrm{B} \& \mathrm{~B}$ transaction. The probability of being a target in a $\mathrm{B} \& \mathrm{~B}$ transaction is divided into being a platform and being an add-on target.

All the explanatory variables for the companies involved in a transaction correspond to the year before the transaction. The characteristics of the control group equal the mean values of the variables during the analyzed time period of 2000 to 2008 . For variable description refer to Section 4.3 and the Appendix.

Table 3 reports the pairwise correlation coefficients between various explanatory variables used in the Logit regression analyses and their statistical significance at the $5 \%$ level. The 
highest correlation of nearly minus $32 \%$ is measured between the profitability measure and the debt ratio. The higher the profitability of the firm the lower its indebtedness. Furthermore, the significant negative relationship between HHI and number of deals indicates that more transactions take place in less concentrated industries.

The coefficients of the Logit regressions are presented in Table 4. Table 4 is divided into six panels (A through $\mathrm{F}$ ) which correspond to the transaction types private equity, $\mathrm{B} \& \mathrm{~B}$ platforms and $\mathrm{B} \& \mathrm{~B}$ add-ons. Panels $\mathrm{A}$ to $\mathrm{C}$ show the results of the logit models without and Panels D to F with the profitability variable in order to control for potential multicollinearity problems arising from the relatively high negative correlation between ROA and DEBT. The Chow test columns show the results from tests on the coefficients' equality based on seemingly unrelated regressions for the $\mathrm{PE}$ targets compared to the $\mathrm{B} \& \mathrm{~B}$ sample. Table 5 presents the marginal effects of the explanatory variable.

In line with the growth-resource mismatch hypothesis of Barnes (2000) following which low-growth and resource-rich firms are natural acquisition targets, we find that a good profitability combined with a poor growth increases a firm's likelihood of being an add-on in B\&B. For the two other samples, the relationship between a firm's profitability and the probability of being involved in a transaction is also positive and statistically and economically significant. These results provide confirmation of Hypothesis 1a and suggest that PE investors select more profitable firms to invest in. However, we do not find any significant difference between the impact of profitability for platforms and add-ons.

While turnover GROWTH has no significant influence on the selection of a target for a usual PE transaction, higher GROWTH increases the probability of being selected as a platform in B\&B. This finding is in line with the results of Andrade and Stafford (2004) who show that growing acquirers can use mergers for expanding reasons. Furthermore, we find a significant difference between the positive coefficient of GROWTH in the platform equation and the negative coefficient in the add-on equation. The opposite signs for platforms and add-ons suggest that within B\&B, growing firms seek to take over firms which are growing more slowly and whose assets they can utilize more successfully. The Chow tests show that the coefficients of GROWTH in the PE and platform equations differ significantly which is an indication for the divergent selection criteria which are applied by the PE investors for usual PE targets and for platforms. 
The significant positive impact of capacity utilization, measured as the ratio of turnover to total assets, on the transaction probability is not consistent with the findings of Jensen (1993) and Andrade and Stafford (2004) for the 1970s and 1980s that mergers were motivated by excess capacity. The positive relationship is consistent with the evidence of Andrade and Stafford (2004) for the 1990s that mergers can be motivated by expansion goals. It seems that in the case of $\mathrm{PE}$ targets the investors prefer firms with a higher turnover per firm's assets. When executing a B\&B the investors may reallocate assets among the platform and add-ons in order to increase the efficiency of the groups. Therefore, it is surprising that there is no significant difference between the coefficients of capacity utilization for both the platforms and add-ons. Capacity utilization has a similar effect on the probability of being a platform or an add-on in a B\&B.

The results reveal that firm SIZE is significantly positively related to the probability of being involved in a PE or B\&B transaction. The Chow tests show that larger SIZE is most important for platforms and less important for add-ons in B\&B. This results correspond to the findings for acquirers in $\mathrm{M} \& \mathrm{~A}$ which indicate that large firms have more resources for executing acquisitions and have a greater potential for realizing synergies after the transactions. The positive signs of SIZE for the add-ons are not consistent with the findings of Palepu (1985). Nevertheless, they are in line with the growth-maximization theory of Mueller (1972). This implies that PE investors seek to achieve economies of scale or market power through larger acquisitions.

The growth-resource imbalance hypothesis of Palepu (1986) indicates that, additionally to the GROWTH of a firm, its liquidity is an important variable determining an acquisition. Following Palepu, we proxy the financial resource availability by DEBT. The marginal effects in Table 5 show that DEBT is significantly negatively related to the likelihood of being a target in a PE transaction. This result is consistent with our expectations that investors would select firms with sufficient free debt capacity in order to absorb the additional leverage from financing the transaction. However, the impact of DEBT on the probability of executing a $\mathrm{B} \& \mathrm{~B}$ transaction is insignificant. Furthermore, we do not find any significant differences between the influence of DEBT in the PE and B\&B models.

As expected, decreasing industry concentration, measured as the HHI, increases the likelihood of being acquired as a platform for B\&B by a PE investor. More fragmented 
industries have a higher number of potential add-ons and provide industry consolidation opportunities. The Chow tests indicate that the impact of HHI on B\&B and PE transactions differs significantly.

In line with the preference of many PE investors to specialize in selected industries, we find that a higher number of executed deals in the firm's industry and country in the year prior to the respective transaction increases the probability for this firm to be involved in a transaction. This effect is highly statistically and economically significant, indicating that the investors use their experience and industry know-how from previous deals.

\subsection{Value creation effect}

To assess the value creation effect, we evaluate the impact of participation in a transaction on the development of firms' financial characteristics. We first examine the changes of the firms' financial ratios during the three years after the $\mathrm{PE}$ and $\mathrm{B} \& \mathrm{~B}$ transaction compared to the year prior to the respective transaction. Second, we apply multivariate panel regressions with firms fixed effects to assess the impact of participation in a $\mathrm{B} \& \mathrm{~B}$ on the development of selected financial characteristics and to identify the potential for value creation.

\subsubsection{Univariate analyses}

The analysis of post-transaction changes of firm characteristics focuses on the percentage changes in total assets, turnover and EBITDA as well as the ratios EBITDA to total assets, debt to total assets, and turnover to total assets in the first three years after the deal completion $(\mathrm{T}=+1,+2$ and +3 ) relative to the last year prior to the transaction $(t=-1)$. For comparison reasons we also calculate the last annual change prior to the transaction (from $\mathrm{t}=-2$ to $\mathrm{t}=-1$ ). ${ }^{7}$ We control for industry-wide effects by analysing also the industry-adjusted percentage change in the variables. The industry-adjusted change is the median value of the industry-adjusted changes for all firms involved in $\mathrm{PE}$ or $\mathrm{B} \& \mathrm{~B}$ transactions. The firm specific industry-adjusted change is calculated as the percentage change in the analyzed variables for the firm minus the median percentage change for all firms in the same industry and country. Firms belong to the same industry if they

\footnotetext{
${ }^{7}$ This approach is similar to that used by Kaplan (1989).
} 
have the same two-digit NACE code as a primary industry code. In contrast to Kaplan (1989), who uses four-digit SIC codes, we aggregate the industries to two-digits to ensure a sufficient number of matches even for smaller countries and industries. ${ }^{8}$

Similar to Kaplan (1989) we do not present results for the year of the transaction, year 0, due to interpretation problems. First, year 0 includes both pre- and post-transaction operations. Second, the financial information could be biased because of transactionrelevant fees or specific accounting features in the year of consolidation.

Since further M\&A or divestiture activities, which occur after the relevant transaction, also affect the financial characteristics of the firms, we consider the post-transaction observations for such firms only until the year at which the exit or the further transaction is executed.

Table 6 reports the development of selected financial characteristics from two years prior to the transaction to three years after the transaction. The total assets for B\&B firms (platforms and add-ons) increase significantly in all three years after the transaction compared to the level in the last year prior to the transaction. Even, when controlling for industry effects, the growth in total assets remains significant for platforms in the years +1 and +2 and for add-ons only in the year +1 . In contrast, for PE targets the total assets significantly increase during all analyzed years even after industry adjustments.

In line with the results of the logit regression, the add-ons achieve lower (industry adjusted) turnover growth and higher (industry adjusted) profitability growth, measured in absolute values (EBITDA) and as ratio EBITDA to total assets, in the year prior to the transaction compared to the platforms. However, after the transaction the platforms realize larger industry-adjusted turnover and profitability growth.

The most interesting result pertains to the development of capacity utilization, measured as the ratio of turnover to total assets, as it ties in directly to the allocation function of $\mathrm{PE}$ investors discussed above. Combining platforms with lower utilization and add-ons with higher utilization, the PE investors allocate resources and capacity more efficiently. We find initial evidence supporting Hypothesis 3 as in the years two and three after the B\&B, the industry-adjusted utilization of the platforms increases significantly and the utilization

\footnotetext{
${ }^{8}$ While Kaplan (1989) uses data on US firms we analyze the EU-15 countries which contain smaller countries such as Greece or Austria.
} 
of the add-ons decreases significantly in the first year after the transaction. The industryadjusted development of utilization for common PE targets is positive as well but not as strong.

While we find a highly significant industry-adjusted increase in the debt ratio for platforms in the years one to three after the transaction, the development of the debt ratio for addons is insignificant with the exception of the year +1 where it is moderate and slightly significant. The debt ratio for PE targets also increases significantly but the growth is lower than for the platforms. This univariate analysis shows that $\mathrm{B} \& \mathrm{~B}$ trigger the high indebtedness especially of platforms.

\subsubsection{Multivariate regressions}

Next, we employ a multivariate panel regression to investigate the impact of transactions on firms' financial figures and to identify the sources of value creation. The firm panel includes financial characteristics of firms involved in $\mathrm{PE}$ and $\mathrm{B} \& \mathrm{~B}$ transactions, and their matchings in all available years. For each of the variables of interest - ratios of total debt to total assets, EBITDA to total assets and turnover to total assets and turnover growth $\left(Y_{j}, t\right)$ - we estimate four model specifications. The first one includes a dummy variable for the whole post-transaction period "POST" and an interaction term for the firms involved in a transaction in the post-transaction period "POST*TRANS". The second specification comprises dummies for the first three post-transaction years separately "POST1", "POST2", and "POST3" and an interaction term with each of them for the treated firms. Additionally, the first and second specification are re-estimated by including a lagged dependent variable.

$$
\begin{aligned}
\mathrm{Y}_{j t}=\phi_{0} & +\phi_{1} \mathrm{POST}+\phi_{2} \mathrm{POST} * \text { TRANS }+\phi_{3} \text { TRANS }+\phi_{4} \mathrm{Y}_{j t-1}+\Phi_{5} \overrightarrow{D_{t}}+\Phi_{6} \overrightarrow{D_{f}}+u_{j t-1} \\
\mathrm{Y}_{j t} & =\phi_{0}+\phi_{1} \mathrm{POST} 1+\phi_{2} \mathrm{POST} 2+\phi_{3} \mathrm{POST} 3 \\
& +\phi_{4} \mathrm{POST} 1 * \text { TRANS } 1+\phi_{5} \mathrm{POST} 2 * \text { TRANS } 2+\phi_{6} \mathrm{POST} 3 * \text { TRANS } 3 \\
& +\phi_{7} \text { TRANS } 1+\phi_{8} \mathrm{TRANS} 2+\phi_{9} \text { TRANS3 } \\
& +\phi_{10} \mathrm{Y}_{j t-1}+\Phi_{11} \overrightarrow{D_{t}}+\Phi_{12} \overrightarrow{D_{f}}+u_{j t-1}
\end{aligned}
$$


We employ firm fixed effects to control for time-invariant, unobservable firm characteristics and use year dummy variables to account for time-varying conditions. As errors are unlikely to be independent, we cluster them by company.

Finally, we split the sample into four groups. Firms with an industry-adjusted growth or decrease of capacity utilization and firms with industry-adjusted growth or decrease in debt ratio.

The results of the panel regressions which are presented in Table 7 confirm the findings of the pre- and post-transaction analysis. The positive coefficients of the interaction terms "TRANS*POST" indicate that the leverage level for firms involved in a transaction increases after the transaction. This effect seems to be stronger for platforms than for $\mathrm{PE}$ targets and it is insignificant for add-ons. As expected, platform companies seem to receive the leveraged financing of both the own acquisition and the financing of the addons. The negative coefficient of "POST" for PE targets and their control firms suggest a debt decline after the year observed as a transaction year.

In support of Hypothesis 3b, we find different signs of the coefficients on the interaction terms for the ratio turnover to total assets which is the proxy for capacity utilization for platforms and add-ons. While for add-ons, the participation in a B\&B induces a significant negative effect on the firm's capacity utilization, the effect for platforms is positive, but insignificant. Especially in the first year after the B\&B, the high initial utilization of add-ons decreases significantly. It seems that add-ons receive additional capacity which reduces their realized turnover per asset. These results indicate that PE funds use B\&B to reallocate resources between the participating firms in order to realize efficiency gains. We find a limited support of Hypothesis $2 \mathrm{~b}$ as B\&B increase the turnover growth significantly only of the platforms in the first year after the transaction. The results of the panel regressions show a strong persistence in the development of all dependent variables except of turnover growth. We find a significantly positive relationship between the variables $\mathrm{ROE}$, the ratios debt to total assets and turnover to total assets and their lagged values and a significantly negative impact of the lagged turnover growth.

According to Gugler et al. (2003) transactions which increase the efficiency of the involved firms should increase both their profits and their turnover. As we did not find a confirmation of Hypothesis 1c for the whole samples of PE targets, platforms and add-ons, we split the samples into subsamples of firms with growing or decreasing industry adjusted ratio of 
turnover to total assets and subsamples of growing or decreasing debt ratios, respectively. The results of the panel regressions after the sample splits show that for platforms and add-ons which increase their capacity utilization the profitability improves after the transaction (see Table 8). Thus, B\&B lead to efficiency increase. In contrast, for platforms with decreasing utilization the transaction leads to a negative effect on profitability. The coefficient for add-ons is the same but insignificant.

Furthermore, B\&B and PE transactions have a positive impact on profitability for firms with decreasing indebtedness. For PE targets and add-ons the industry adjusted debt ratios of which increase, the profitability worsens after the transaction. These results contradict the positive effect of debt described by Jensen (1989) which could be due to the relatively short time period analyzed after the transaction.

\section{Conclusion}

This paper describes a key strategy of private equity firms, the buy-and-build strategy, and sheds light on the sources for value creation through buy-and-builds. The B\&B is a PE-backed M\&A transaction: The PE investor acquires a platform firm and amend it by further acquisition of add-on firms. The aim is to create a new entity which is superior in terms of performance and in terms returns upon exit which the PE investment envisaged. The evaluation of the selection effect in buy-and-builds and the development of firm characteristics after buy-and-builds enables the identification of value-adding potential.

Based on a sample of 844 firms involved in buy-and-builds between 2000 and 2008 in the EU-15, we show that the selection of well performing firms prior to the transaction plays a key role for the performance improvement of the portfolio firms after the transaction. However, we find additional value enhancing potentials which private equity investors may explore through buy-and-builds.

The results on the development of capacity utilization after the buy-and-build in addition to the pre-transaction analysis provide evidence that private equity funds might use buyand-builds to combine platforms with lower capacity utilization and lower returns, and add-ons with higher utilization and higher returns in order to allocate resources and capacity more efficiently. The low pre-transaction capacity utilization of platforms increases 
after buy-and-builds, and the high pre-transaction utilization of add-ons decreases after the transaction. However, only for the subsamples of platforms and add-ons with increasing industry adjusted utilization, the transaction has a positive impact on firms' profitability, suggesting that not the removal of excess capacity drives the positive performance but the increase of realized turnover per asset unit.

This is the first study to provide empirical evidence on the role of private equity funds in facilitating mergers \& acquisitions for portfolio firms and in creating value by applying buy-and-build strategies. The performance improvements indusced by PE investors may be explained by their engagement in shifting resources to more efficient uses and to better managers but also by helping their portfolio companies to develop networks, to overcome asymmetric information problems and to improve the exit chances. Thus, buy-and-builds represent a key dimension of the value creation ability of private equity funds. 


\section{Appendix}

Variable description and sources

\begin{tabular}{ll}
\hline VARIABLE & DESCRIPTION \\
\hline SIZE & Firm size measured as firm's total assets. We use the log of \\
& the variable. Source: Amadeus \\
HHI & Industry concentration proxied by the Herfindahl- \\
& Hirschman-Index (HHI) for each two-digit US-SIC code \\
& industry. HHI is defined as the sum of the squares of the \\
& market shares of each company in an industry, country, and \\
& year. Source: Amadeus \\
& Number of private equity or B\&B transaction in a two-digit \\
& NACE Rev.2 industry code and country in the time period \\
& 2000-2008. Source: Zephyr \\
& Firm growth measured as the turnover growth per year. \\
& Source: Amadeus \\
& The ratio of total debt to total assets for each firm. Defi- \\
GROWTH & nitions and approach follow Baeyens and Manigart (2006). \\
& Source: Amadeus \\
DEBT & Return on assets for each firm, calculated as the ratio of the \\
& earnings before interests, taxes, depreciations and amortiza- \\
& tions (EBITDA) to the book value of total assets. Source: \\
& Amadeus \\
ROA & Capacity utilization measured by the ratio of turnover to \\
&
\end{tabular}




\section{References}

[1] J. W. Allen and G. M. Phillips. Corporate equity ownership, strategic alliances, and product market relationships. The Journal of Finance, 55(6):279-2815, 2000.

[2] J. M. Anapolsky. How to structure and manage leveraged build-ups. The Journal of Private Equity, 1:33-50, 1998.

[3] G. Andrade and E. Stafford. Investigating the economic role of mergers. Journal of Corporate Finance, 10(1):1-36, January 2004.

[4] K. Baeyens and S. Manigart. Who gets private equity? The role of debt capacity, growth and intangible assets. Working Papers of Faculty of Economics and Business Administration, Ghent University, Belgium 06/368, Ghent University, Faculty of Economics and Business Administration, 2006.

[5] G. P. Baker and K. H. Wruck. Organizational changes and value creation in leveraged buyouts: The case of the O.M. Scott \& Sons Company. Journal of Financial Economics, 25(2):163-190, 1989.

[6] P. Barnes. The identification of U.K. takeover targets using published historical cost accounting data. International Review of Financial Analysis, 9(2):147-162, 2000.

[7] R. Brealey and S. Myers. Principles of Corporate Finance. McGraw-Hill, New York, NY, 2003.

[8] K. C. Brown, A. Dittmar, and H. Servaes. Corporate governance, incentives, and industry consolidations. Review of Financial Studies, 18(1):241-270, 2005.

[9] R. Cressy, F. Munari, and A. Malipiero. Playing to their strengths? Evidence that specialization in the private equity industry confers competitive advantage. Journal of Corporate Finance, 13(4):647-669, 2007.

[10] S. J. Davis, J. Haltiwanger, R. Jarmin, J. Lerner, and J. Miranda. Private equity, jobs and productivity. In The Global Economic Impact of Private Equity Report 2009, chapter 2, pages 27-43. World Economic Forum, January 2009. 
[11] E. Devos, P.-R. Kadapakkam, and S. Krishnamurthy. How do mergers create value? a comparison of taxes, market power, and efficiency improvements as explanations for synergies. Review of Financial Studies, 22:1179-1211, 2008.

[12] F. J. Fabozzi. The Handbook of Financial Instruments. Wiley, 2002.

[13] P. Fernandez. Valuation Methods and Shareholder Value Creation. Academic Press, San Diego, CA., 2002.

[14] P. A. Gompers, A. Kovner, J. Lerner, and D. Scharfstein. Venture capital investment cycles: The impact of public markets. Journal of Financial Economics, 87(1):1-23, 2008.

[15] P. A. Gompers and J. Lerner. The determinants of corporate venture capital success: Organizational structure, incentives, and complementarities. In Randall Morck, ed., Concentrated Ownership. Chicago: University of Chicago Press, page 17-50, 2000.

[16] L. Goossens, S. Manigart, and M. Meuleman. The change in ownership after a buyout: Impact on performance. Journal of Private Equity, 12(1):31-41, 2008.

[17] K. Gugler, D. C. Mueller, B. B. Yurtoglu, and C. Zulehner. The effects of mergers: an international comparison. International Journal of Industrial Organization, 21(5):625-653, May 2003.

[18] J. Harford. What drives merger waves? Journal of Financial Economics, 77(3):529560, September 2005.

[19] P. M. Healy, K. G. Palepu, and R. S. Ruback. Does corporate performance improve after mergers? Journal of Financial Economics, 31(2):135-175, 1992.

[20] N. Hoffmann. German buyouts adopting a buy and build strategy. Master's thesis, Martin-Luther-Universität Halle-Wittenberg, 2008.

[21] C. G. Holderness. A survey of blockholders and corporate control. Economic Policy Review, (Apr):51-64, 2003.

[22] N. Huyghebaert and M. Luypaert. Antecedents of growth through mergers and acquisitions: Empirical results from Belgium. Journal of Business Research, 63(4):392-403, 2010. 
[23] M. C. Jensen. Agency costs of free cash flow, corporate finance, and takeovers. The American Economic Review, 76(2):323-329, 1986.

[24] M. C. Jensen. Eclipse of the public corporation. Harvard Business Review, 67(5):6174, 1989.

[25] M. C. Jensen. The modern industrial revolution, exit, and the failure of internal control systems. The Journal of Finance, 48(3):831-880, 1993.

[26] S. N. Kaplan and P. Strömberg. Characteristics, contracts, and actions: Evidence from venture capitalist analyses. The Journal of Finance, 59(5):2177-2210, 2004.

[27] S. N. Kaplan and P. Strömberg. Leveraged buyouts and private equity. Journal of Economic Perspectives, 23(1):121-46, Winter 2009.

[28] K. Lehn, J. Netter, and A. Poulsen. Consolidating corporate control: Dual-class recapitalizations versus leveraged buyouts. Journal of Financial Economics, 27(2):557$580,1990$.

[29] L. Lindsey. Blurring firm boundaries: The role of venture capital in strategic alliances. The Journal of Finance, 63(3):1137-1168, 2008.

[30] V. Maksimovic and G. Phillips. The market for corporate assets: Who engages in mergers and asset sales and are there efficiency gains? Journal of Finance, 56:20192065, 2001.

[31] M. Martynova and L. Renneboog. A century of corporate takeovers: What have we learned and where do we stand? Journal of Banking \& Finance, 32(10):2148-2177, October 2008.

[32] M. L. Mitchell and J. H. Mulherin. The impact of industry shocks on takeover and restructuring activity. Journal of Financial Economics, 41(2):193-229, June 1996.

[33] D. C. Mueller. A life cycle theory of the firm. Journal of Industrial Economics, 20(3):199-219, July 1972.

[34] E. Nikoskelainen and M. Wright. The impact of corporate governance mechanisms on value increase in leveraged buyouts. Journal of Corporate Finance, 13(4):511-537, 2007. 
[35] T. C. Opler. Operating performance in leveraged buyouts: Evidence from 1985 1989. Financial Management, 21(1), Spring 1992.

[36] T. C. Opler and S. Titman. The determinants of leveraged buyout activity: Free cash flow vs. financial distress costs. The Journal of Finance, 48(5):1985-1999, 1993.

[37] K. G. Palepu. Predicting takeover targets : A methodological and empirical analysis. Journal of Accounting and Economics, 8(1):3-35, March 1986.

[38] F. Pasiouras and S. Tanna. The prediction of bank acquisition targets with discriminant and logit analyses: Methodological issues and empirical evidence. Research in International Business and Finance, 24(1):39-61, 2010.

[39] R. Powell and A. Yawson. Industry aspects of takeovers and divestitures: Evidence from the UK. Journal of Banking \&f Finance, 29(12):3015-3040, 2005.

[40] D. S. Prijcker, S. Manigart, M. Wright, and D. M. Maeseneire. The influence of international human capital and international network relationships on the cross-border investment behaviour of private equity firms. Technical report, Ghent University Working Paper 2009/597, 2009.

[41] D. J. Ravenscraft and F. M. Scherer. Life after takeover. Journal of Industrial Economics, 36(2):147-56, December 1987.

[42] P. R. Rosenbaum and D. B. Rubin. The central role of the propensity score in observational studies for causal effects. Biometrika, 70:41-55, 1983.

[43] P. C. Rousseau. Joint acquisitions by financial and strategic buyers: An overview of key business and legal issues. The Journal of Private Equity, 14:53-60, 2010.

[44] A. Schertler and T. Tykvová. Venture capital and internationalization. International Business Review, 20:423-439, 2011.

[45] A. Shleifer and R. W. Vishny. A survey of corporate governance. Journal of Finance, 52(2):737-83, June 1997.

[46] C. P. Silverfleet. Buy and Build Monitor. Technical report, Silverfleet Capital Partners LLP, 2010. 
[47] H. T. J. Smit. Acquisition strategies as option games. Journal of Applied Corporate Finance, 14(2):79-89, 2001.

[48] A. J. Smith. Corporate ownership structure and performance: The case of management buyouts. Journal of Financial Economics, 27(1):143-164, 1990.

[49] J. J. Stephen A. Ross, Randolph W. Westerfield. Corporate Finance. McGraw-Hill Companies, 2002.

[50] E. Trahan and H. Shawky. Financial characteristics of acquiring firms: an industry specific approach. Review of Financial Economics, 48 7:81-94, 1992.

[51] T. Tykvova and M. Borell. Do private equity owners increase risk of fi nancial distress and bankruptcy? Journal of Corporate Finance, 18:138-150, 2012. 


\section{Table 1}

Number of companies involved in buy-and-build strategies as platforms and add-ons by year, country and industry

Panel A: Breakdown by year

\begin{tabular}{llll}
\hline & $\begin{array}{l}\text { Buy-and-Build } \\
\text { (total) }\end{array}$ & Platform & Add-on \\
\hline 2000 & 11 & 3 & 8 \\
2001 & 2 & 1 & 1 \\
2002 & 17 & 8 & 9 \\
2003 & 27 & 13 & 14 \\
2004 & 36 & 17 & 19 \\
2005 & 98 & 43 & 55 \\
2006 & 162 & 52 & 110 \\
2007 & 225 & 71 & 154 \\
2008 & 266 & 89 & 177 \\
Total & $\mathbf{8 4 4}$ & $\mathbf{2 9 7}$ & $\mathbf{5 4 7}$ \\
\hline
\end{tabular}

Panel B: Breakdown by country

\begin{tabular}{llll}
\hline & $\begin{array}{l}\text { Buy-and-Build } \\
\text { (total) }\end{array}$ & Platform & Add-on \\
\hline United Kingdom & 246 & 84 & 162 \\
France & 192 & 69 & 123 \\
Spain & 76 & 31 & 45 \\
Germany & 65 & 25 & 40 \\
Sweden & 57 & 24 & 33 \\
Italy & 49 & 14 & 35 \\
Netherlands & 39 & 12 & 27 \\
Belgium & 38 & 13 & 25 \\
Finland & 36 & 10 & 26 \\
Denmark & 21 & 5 & 16 \\
Portugal & 9 & 4 & 5 \\
Ireland & 8 & 2 & 6 \\
Austria & 4 & 3 & 1 \\
Greece & 3 & 1 & 2 \\
Luxembourg & 1 & & 1 \\
Total & $\mathbf{8 4 4}$ & $\mathbf{2 9 7}$ & $\mathbf{5 4 7}$ \\
\hline
\end{tabular}


Table 2

Summary statistics of firms involved in a buy-and-build strategy versus firms not involved in a buy-and-build strategy

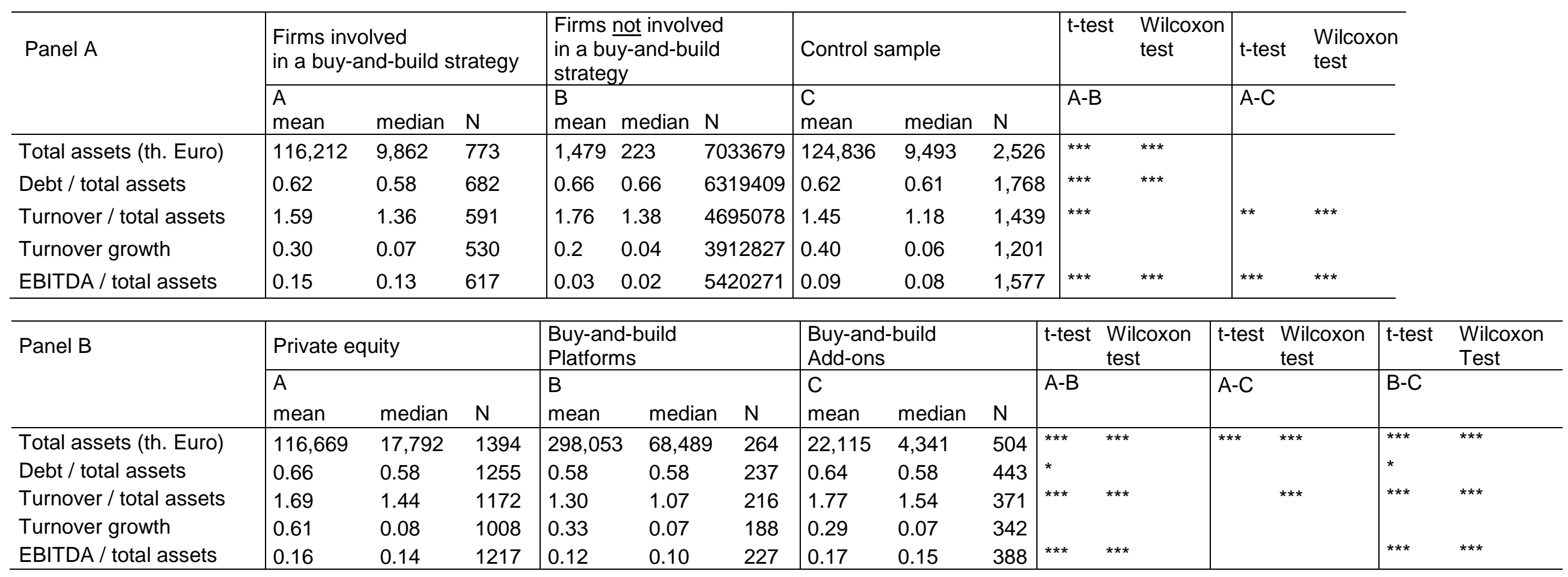

This table reports summary statistics of firms involved in a buy-and-build strategy during the time period 2000 to 2008 versus firms not involved in a buy-and-build

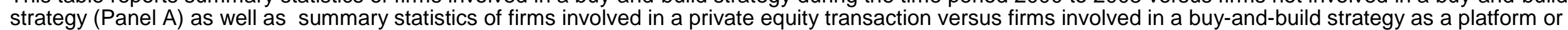

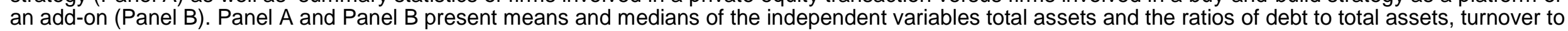
total assets, turnover growth and EBITDA to total assets. The data for the firms involved in a buy-and-build or private equity transaction corresponds to the year before the transaction. The data for the control group corresponds to the median values for the time period 1999 to 2008 . Variable definitions are provided in the Appendix. The number of observations varies across items due to data availability. I test for the equality of means (t-test allowing for unequal variances) and the equality of distributions (Wilcoxon-Mann-Whitney test) between each two groups of firms. ***, **, * denote significance at the $1 \%, 5 \%$ and $10 \%$ level, respectively. 
Table 3

Bivariate correlations for the independent variables

\begin{tabular}{|c|c|c|c|c|c|c|c|}
\hline & 1 & 2 & 3 & 4 & 5 & 6 & 7 \\
\hline 1. Total assets & 1 & & & & & & \\
\hline 2. Debt / total assets & $-0.1519^{*}$ & 1 & & & & & \\
\hline 3. Turnover / total assets & $-0.2681^{*}$ & $0.1655^{\star}$ & 1 & & & & \\
\hline 4. Turnover growth & $-0.0472^{\star}$ & $0.0676^{\star}$ & $-0.0248^{*}$ & 1 & & & \\
\hline 5. EBITDA / total assets & $-0.0376^{\star}$ & $-0.3157^{*}$ & $0.1396^{\star}$ & $-0.0387^{*}$ & 1 & & \\
\hline 6. $\mathrm{HHI}$ & $0.0119^{*}$ & $-0.0225^{\star}$ & $0.0165^{\star}$ & $-0.0041^{*}$ & $0.0352^{*}$ & 1 & \\
\hline 7. Number deals & $-0.0104^{*}$ & $0.0062^{\star}$ & $0.1363^{\star}$ & $-0.0068^{\star}$ & $0.0276^{\star}$ & $-0.1792^{\star}$ & 1 \\
\hline
\end{tabular}

This table shows the correlations of the independent variables used in the logit regression analysis. Variable definitions are provided in the Appendix. * Denotes significance of the correlation coefficients at the $5 \%$ level. 
Table 4

Firm and industry characteristics influencing the probability of being involved in a private equity or buy-and-build transaction

\begin{tabular}{|c|c|c|c|c|c|c|c|c|c|c|c|c|}
\hline & \multirow{2}{*}{$\begin{array}{c}\begin{array}{c}\text { Private } \\
\text { equity }\end{array} \\
\mathrm{A}\end{array}$} & \multirow{2}{*}{$\begin{array}{l}\text { Platforms } \\
\text { B } \\
\end{array}$} & \multirow{2}{*}{$\begin{array}{l}\text { Add-ons } \\
\text { C } \\
\end{array}$} & \multicolumn{3}{|c|}{ Chow-Tests } & \multirow{2}{*}{$\begin{array}{l}\begin{array}{c}\text { Private } \\
\text { equity }\end{array} \\
\mathrm{D}\end{array}$} & \multirow{2}{*}{$\begin{array}{l}\text { Platforms } \\
\text { E }\end{array}$} & \multirow{2}{*}{$\begin{array}{l}\text { Add-ons } \\
\mathrm{F} \\
\end{array}$} & \multicolumn{3}{|c|}{ Chow-Tests } \\
\hline & & & & $A-B$ & $A-C$ & $\mathrm{~B}-\mathrm{C}$ & & & & D-E & $\mathrm{D}-\mathrm{F}$ & $\mathrm{E}-\mathrm{F}$ \\
\hline Total assets (log) & $\begin{array}{l}0.722^{\star \star \star} \\
(0.009)\end{array}$ & $\begin{array}{l}0.831^{\star \star \star} \\
(0.020)\end{array}$ & $\begin{array}{l}0.637^{\star \star \star} \\
(0.015)\end{array}$ & $\begin{array}{l}\star \star \star \\
(26.56)\end{array}$ & $\begin{array}{l}\star \star \star \\
(25.31)\end{array}$ & $\begin{array}{l}\star \star \star \\
(64.20)\end{array}$ & $\begin{array}{l}0.752^{\star \star \star} \\
(0.010)\end{array}$ & $\begin{array}{l}0.854^{\star * *} \\
(0.021)\end{array}$ & $\begin{array}{l}0.672^{\star \star \star} \\
(0.017)\end{array}$ & $\begin{array}{l}\star \star \star \\
(19.93)\end{array}$ & $\begin{array}{l}\star \star \star \\
(17.39)\end{array}$ & $\begin{array}{l}\star \star \star \\
(46.20)\end{array}$ \\
\hline Debt / total assets & $\begin{array}{l}-0.339 * \star \\
(0.135)\end{array}$ & $\begin{array}{l}-0.040 \\
(0.319)\end{array}$ & $\begin{array}{l}-0.121 \\
(0.230)\end{array}$ & $(0.75)$ & $(0.67)$ & $(0.04)$ & $\begin{array}{l}-0.026 \\
(0.140)\end{array}$ & $\begin{array}{l}0.158 \\
(0.316)\end{array}$ & $\begin{array}{l}0.066 \\
(0.245)\end{array}$ & $(0.29)$ & $(0.11)$ & $(0.05)$ \\
\hline Turnover / total assets & $\begin{array}{l}0.228^{\star \star \star} \\
(0.020)\end{array}$ & $\begin{array}{l}0.189 \star \star \star \\
(0.051)\end{array}$ & $\begin{array}{l}0.225^{\star \star \star} \\
(0.028)\end{array}$ & $(0.50)$ & $(0.01)$ & $(0.38)$ & $\begin{array}{l}0.144^{\star \star \star} \\
(0.023)\end{array}$ & $\begin{array}{l}0.114^{*} \\
(0.062)\end{array}$ & $\begin{array}{l}0.178^{\star \star \star} \\
(0.032)\end{array}$ & $(0.21)$ & $(0.77)$ & $(0.85)$ \\
\hline Turnover growth & $\begin{array}{l}0.014 \\
(0.056)\end{array}$ & $\begin{array}{l}0.250 \star \star \star \\
(0.093)\end{array}$ & $\begin{array}{l}-0.056 \\
(0.114)\end{array}$ & $\begin{array}{l}\star \star \\
(4.73)\end{array}$ & $(0.30)$ & $\begin{array}{l}* \star \\
(4.31)\end{array}$ & $\begin{array}{l}-0.035 \\
(0.068)\end{array}$ & $\begin{array}{l}0.197 \\
(0.122)\end{array}$ & $\begin{array}{l}-0.050 \\
(0.130)\end{array}$ & $\begin{array}{l}* \\
(2.78)\end{array}$ & $(0.01)$ & $(1.93)$ \\
\hline EBITDA / total assets & & & & & & & $\begin{array}{l}3.382^{\star \star \star} \\
(0.244)\end{array}$ & $\begin{array}{l}3.178^{\star \star *} \\
(0.567)\end{array}$ & $\begin{array}{l}2.799 \star \star \star \\
(0.467)\end{array}$ & (0.11) & $(1.23)$ & $(0.27)$ \\
\hline $\mathrm{HHI}$ & $\begin{array}{l}0.976 \star \star \\
(0.414)\end{array}$ & $\begin{array}{l}-1.855^{\star} \\
(1.083)\end{array}$ & $\begin{array}{l}0.044 \\
(0.857)\end{array}$ & $\begin{array}{l}* \star \\
(6.06)\end{array}$ & $(0.98)$ & $(1.91)$ & $\begin{array}{l}0.579 \\
(0.451)\end{array}$ & $\begin{array}{l}-2.096^{\star} \\
(1.119)\end{array}$ & $\begin{array}{l}0.031 \\
(0.875)\end{array}$ & $\begin{array}{l}* * \\
(5.01)\end{array}$ & $(0.32)$ & $(2.26)$ \\
\hline Number deals (log) & $\begin{array}{l}0.936^{\star * *} \\
(0.051)\end{array}$ & $\begin{array}{l}1.964^{\star \star \star} \\
(0.165)\end{array}$ & $\begin{array}{l}1.564^{\star \star \star} \\
(0.103)\end{array}$ & & & & $\begin{array}{l}0.941^{\star * \star} \\
(0.052)\end{array}$ & $\begin{array}{l}1.933^{\star \star \star} \\
(0.159)\end{array}$ & $\begin{array}{l}1.532^{\star \star \star} \\
(0.099)\end{array}$ & & & \\
\hline $\begin{array}{l}\text { Industry, country } \\
\text { dummies }\end{array}$ & Yes & Yes & Yes & & & & Yes & Yes & Yes & & & \\
\hline Pseudo $\mathrm{R}^{2}$ & $22.67 \%$ & $26.19 \%$ & $25.33 \%$ & & & & $26.19 \%$ & $25.33 \%$ & $22.67 \%$ & & & \\
\hline No. observations & $1,776,941$ & $1,995,577$ & $1,615,798$ & & & & $1,995,577$ & $1,615,798$ & $1,776,941$ & & & \\
\hline
\end{tabular}

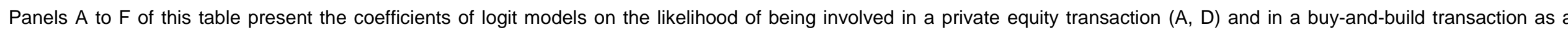

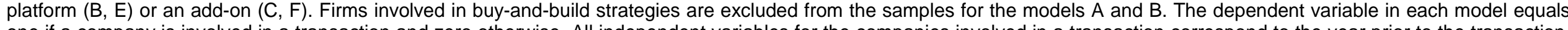

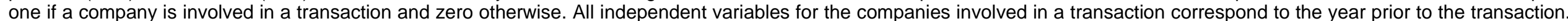

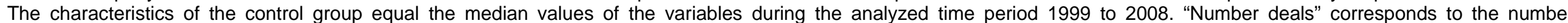

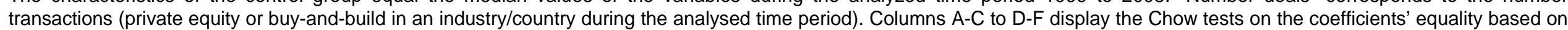

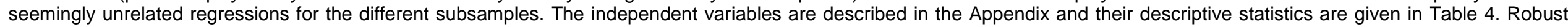
standard errors for the logit models and Chi-squared values for the Chow tests are shown in parentheses. ${ }^{\star \star \star}$, ${ }^{\star *},{ }^{*}$ denote significance at the $1 \%, 5 \%$ and $10 \%$ level, respectively. 
Table 5

Marginal effects after logit for the likelihood of being involved in a buy-and-build, mergers \& acquisitions transaction or private equity transaction

\begin{tabular}{|c|c|c|c|c|c|c|}
\hline & \multicolumn{2}{|c|}{ Private equity } & \multicolumn{2}{|c|}{$\begin{array}{l}\text { Buy-and-build } \\
\text { Platforms }\end{array}$} & \multicolumn{2}{|c|}{$\begin{array}{l}\text { Buy-and-build } \\
\text { Add-ons }\end{array}$} \\
\hline & $A$ & B & C & D & $E$ & $\mathrm{~F}$ \\
\hline Total assets (log) & $0.0427^{\star \star \star}$ & $0.0398^{\star \star \star}$ & $0.00423^{\star \star \star}$ & $0.00396^{\star \star \star}$ & $0.0163^{\star \star \star}$ & $0.0157^{\star \star \star}$ \\
\hline Debt / total assets & $-0.02^{\star \star \star}$ & -0.00137 & -0.000204 & 0.000734 & -0.00311 & 0.00154 \\
\hline Turnover / total assets & $0.0135^{\star \star \star}$ & $0.00762^{\star \star *}$ & $0.000964^{\star \star \star}$ & 0.00053 & $0.00578^{\star \star *}$ & $0.00417^{\star * *}$ \\
\hline Turnover growth & 0.000837 & -0.00187 & $0.00127^{\star \star \star}$ & $0.000914^{\star}$ & -0.00144 & -0.00118 \\
\hline EBITDA / total assets & & $0.1787^{\star \star \star}$ & & $0.0148^{\star \star \star}$ & & $0.0654^{\star \star \star}$ \\
\hline $\mathrm{HHI}$ & $0.0577^{\star \star}$ & 0.0306 & -0.00944 & $-0.00973^{\star}$ & 0.00112 & 0.00724 \\
\hline Number deals (log) & $0.0553^{\star \star \star}$ & $0.0497^{\star \star \star}$ & $0.00999 * \star \star$ & $0.00898^{\star \star \star}$ & $0.0401^{\star \star *}$ & $0.0358^{\star \star \star}$ \\
\hline $\mathrm{Chi}^{2}$ & 3,991 & 4,075 & 1,231 & 1,232 & 1,000 & 1,041 \\
\hline No. observations & $3,474,931$ & $3,369,454$ & $3,470,812$ & $3,365,759$ & $3,473,383$ & $3,365,891$ \\
\hline
\end{tabular}

This table presents the marginal effects on the likelihood of being involved in a private equity transaction or in a buy-and-build strategy as a platform of an addon. All marginal effects are multiplied by 1000 . The dependent variable equals one if a company is involved in a transaction; and zero otherwise. The independent variables are described in the Appendix. The marginal effects are evaluated at the sample means of the independent variables. The robust standard errors for the marginal effects have a very low value of nearly 0 , thus they are not presented. ${ }^{\star \star \star},{ }^{\star \star},{ }^{*}$ denote significance at the $1 \%, 5 \%$ and $10 \%$ level, respectively. 
Table 6

Changes in firm characteristics from the pre-transaction period to the post-transaction period

\begin{tabular}{|c|c|c|c|c|c|c|c|c|c|c|c|c|}
\hline & \multicolumn{4}{|c|}{ Private equity } & \multicolumn{4}{|c|}{$\begin{array}{c}\text { Buy-and-build } \\
\text { Platforms }\end{array}$} & \multicolumn{4}{|c|}{$\begin{array}{l}\text { Buy-and-build } \\
\text { Add-ons } \\
\end{array}$} \\
\hline & -2 to -1 & -1 to +1 & -1 to +2 & -1 to +3 & -2 to -1 & -1 to +1 & -1 to +2 & -1 to +3 & -2 to -1 & -1 to +1 & -1 to +2 & -1 to +3 \\
\hline Total Assets (th. Euro) & 17792 & & & & 68408 & & & & 4275 & & & \\
\hline Percentage change & 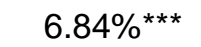 & $10.78 \%$ *** & $15.93 \%$ *** & 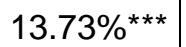 & $7.81 \%$ *** & $18.53 \%$ *** & $12.39 \%$ \%** & $12.74 \%$ ** & 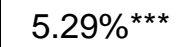 & 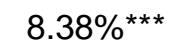 & 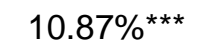 & $9.37 \% *$ \\
\hline Industry adjusted & $3.30 \% * \star \star$ & $4.23 \%$ *** & $5.32 \% * \star \star *$ & $1.54 \% * \star \star$ & $5.00 \% * \star \star *$ & 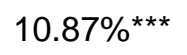 & $3.81 \% *$ & $-4.40 \%$ & $2.95 \%$ *** & $4.66 \%{ }^{\star \star}$ & $2.38 \%$ & $-3.14 \%$ \\
\hline Number observations & 1212 & 845 & 587 & 404 & 227 & 151 & 98 & 53 & 474 & 230 & 138 & 65 \\
\hline Turnover (th. Euro) & 29577 & & & & 64112 & & & & 8825 & & & \\
\hline Percentage change & 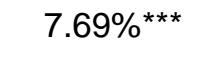 & $12.95 \%$ *** & 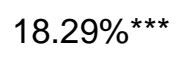 & 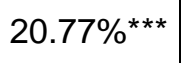 & 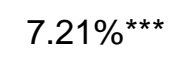 & 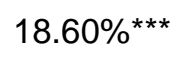 & $32.28 \%$ *** & $33.63 \%$ *** & 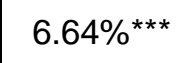 & $5.79 \%$ & 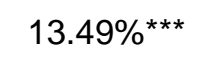 & 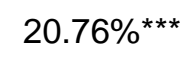 \\
\hline Industry adjusted & 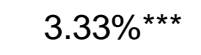 & $4.46 \% \%^{* \star *}$ & $8.11 \% * \star \star$ & $10.30 \%$ *** & $2.15 \%^{* *}$ & 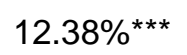 & $20.83 \% \%^{\star \star \star}$ & $25.60 \%$ *** & $0.95 \%^{* \star}$ & $0.24 \%$ & $7.74 \% *$ & $12.68 \% *$ \\
\hline Number observations & 1007 & 684 & 493 & 344 & 190 & 122 & 76 & 43 & 341 & 156 & 93 & 41 \\
\hline EBITDA (th. Euro) & 2428 & & & & 5941 & & & & 908 & & & \\
\hline Percentage change & 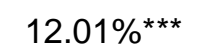 & $15.41 \% \%^{\star \star \star}$ & $19.77 \%$ \%** & $9.78 \% * \star$ & $9.91 \% \%^{\star \star *}$ & $15.88 \% *$ & 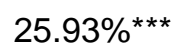 & $19.81 \%$ & 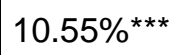 & $3.45 \%$ & $4.25 \%$ & $16.36 \% *$ \\
\hline Industry adjusted & $7.96 \%$ *** & $6.22 \% * \star \star *$ & $10.53 \%$ *** & $5.04 \% * \star$ & $2.70 \% *$ & $6.93 \%$ & $13.73 \% *$ & $18.85 \%$ & $5.09 \%^{\star \star}$ & $0.71 \%$ & $3.85 \%$ & $11.55 \%$ \\
\hline Number observations & 1046 & 720 & 502 & 344 & 193 & 122 & 79 & 44 & 359 & 169 & 99 & 44 \\
\hline EBITDA/TA & 0.14 & & & & 0.10 & & & & 0.15 & & & \\
\hline Percentage change & $3.79 \% * * *$ & $-5.14 \%$ & $-3.23 \%$ & $-15.58 \%$ & $0.09 \%$ & $-8.60 \%$ & $-0.29 \%$ & $7.91 \%$ & $4.13 \% *$ & $-9.86 \%$ & $-12.41 \%$ & $-6.88 \%$ \\
\hline Industry adjusted & $4.83 \% * * *$ & $0.34 \%$ & $3.11 \% * *$ & $-3.53 \%$ & $1.51 \%$ & $-7.21 \%$ & $7.46 \%$ & $19.10 \% *$ & $4.76 \% * *$ & $-6.81 \%$ & $-5.67 \%$ & $9.29 \%$ \\
\hline Number observations & 1045 & 720 & 502 & 344 & 193 & 122 & 79 & 44 & 359 & 169 & 98 & 44 \\
\hline Debt/TA & 0.58 & & & & 0.58 & & & & 0.58 & & & \\
\hline Percentage change & $-0.91 \%$ & $3.24 \% * \star *$ & 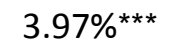 & $6.49 \%$ *** & $2.88 \%^{\star \star}$ & $5.34 \% \%^{\star \star \star}$ & $12.53 \%$ ** & 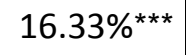 & $-0.63 \%$ & $1.14 \%$ & $-1.32 \%$ & $-0.75 \%$ \\
\hline Industry adjusted & $-0.36 \%$ & $5.14 \%$ *** & $7.49 \%^{\star \star \star}$ & $11.44 \%^{\star \star \star}$ & $3.26 \% * \star \star$ & $8.73 \% * * \star$ & $14.15 \%$ *** & $21.95 \% * \star \star$ & $-0.06 \%$ & $2.99 \% *$ & $2.93 \%$ & $2.43 \%$ \\
\hline Number observations & 1057 & 712 & 490 & 332 & 203 & 129 & 83 & 42 & 392 & 159 & 95 & 46 \\
\hline Turnover/TA & 1.44 & & & & 1.07 & & & & 1.54 & & & \\
\hline Percentage change & $1.53 \%^{\star \star}$ & $1.41 \% *$ & $1.84 \%^{*}$ & $1.98 \%$ & $0.68 \%$ & $1.07 \%$ & $7.11 \%$ & $3.67 \%$ & $0.51 \% *$ & 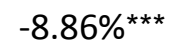 & $-2.19 \%$ & $2.35 \%$ \\
\hline Industry adjusted & $1.69 \%^{\star \star \star}$ & $2.00 \% * \star$ & 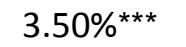 & $4.85 \%^{* *}$ & $1.01 \%$ & $1.79 \%$ & $6.68 \% *$ & $7.65 \% * *$ & $0.44 \% *$ & $-7.54 \% * \star \star$ & $-0.01 \%$ & $7.48 \%$ \\
\hline Number observations & 1006 & 684 & 493 & 344 & 190 & 122 & 76 & 43 & 341 & 155 & 92 & 41 \\
\hline
\end{tabular}




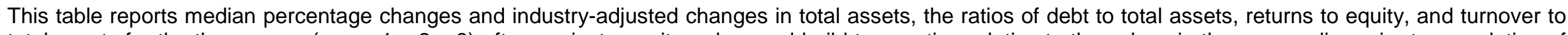
total assets for the three years (year $+1,+2,+3$ ) after a private equity or buy-and-build transaction relative to the values in the year ending prior to completion of the deal (year -1). Industry-adjusted change for a given period equals the difference between the change for the company involved in a transaction and the median change for a sample of companies in the same industry and country during the same period. Variable definitions are provided in the Appendix. The number of observations varies across items due to data availability. Significance levels are based on two-tailed Wilcoxon signed rank tests. ${ }^{\star \star \star},{ }^{\star \star},{ }^{\star}$ denote significance at the $1 \%, 5 \%$ and $10 \%$ level, respectively. 
Table 7

Panel regressions for firms involved in private equity and buy-and-build transactions

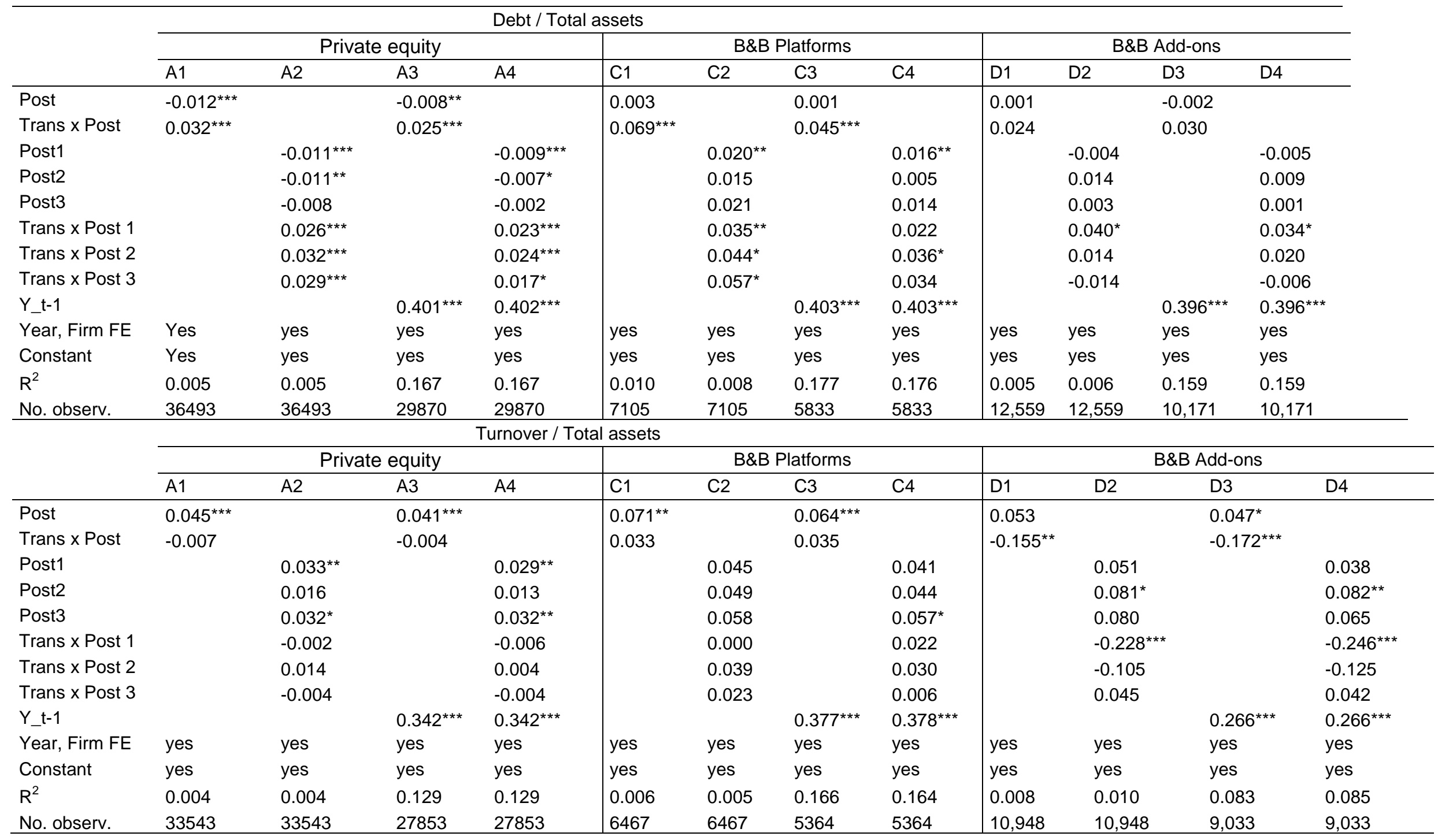




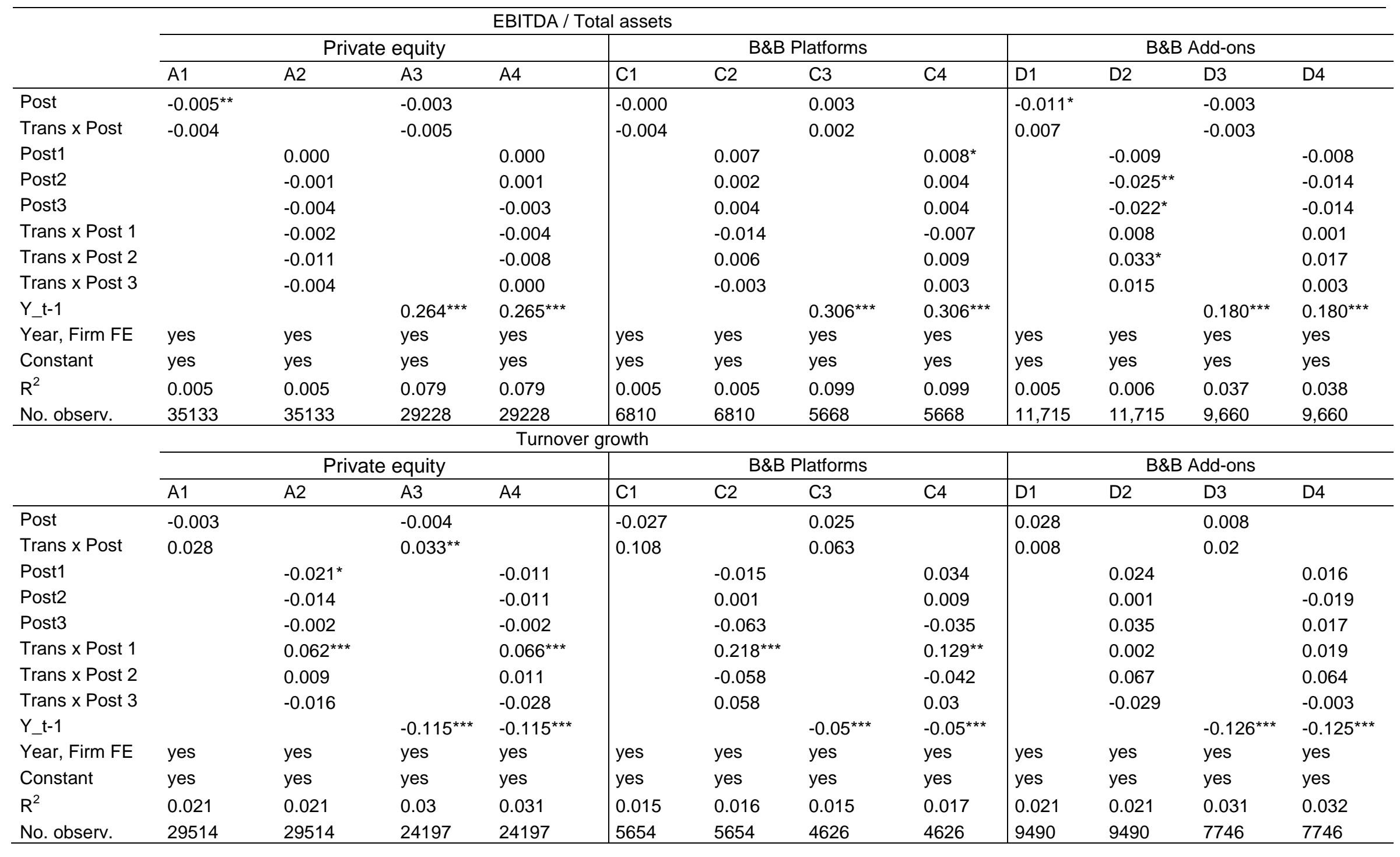


This table reports the results of panel regressions with the dependent variables ratio of EBITDA to total assets (Panel A, return on equity, ROE), ratio of total debt to total assets (Panel B), the ratio of turnover to total assets (Panel C) and the turnover growth (Panel D) - for the samples of PE targets, firms involved in B\&B as a whole, and firms involved in B\&B as platforms or add-ons. "Post" is a dummy variable with a value of one in all years after the transaction for treated and control companies and zero in the years prior to the transactions. "Trans x Post" is an interaction term which equals one for treated companies in all years after the respective transaction. Post1, Post2 or Post3 equal 1 only in the

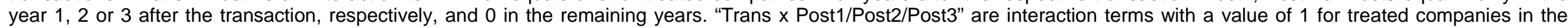
respective year 1, 2 or 3 after the transaction. $Y$ _t-1 denotes a lagged dependent variable. All regressions include a constant, year and firm fixed effects. The standard errors are clustered by company. Variable definitions are provided in the Appendix. ${ }^{* \star}$, **, * denote significance at the $1 \%, 5 \%$ and $10 \%$ level, respectively. 
Table 8

Panel regressions for firms involved in private equity and buy-and-build transactions splitted in subsamples of firms with an industry adjusted Turnover / Total

Assets growth vs. Turnover / Total Assets decline after the transaction

\begin{tabular}{|c|c|c|c|c|c|c|c|c|c|c|c|c|}
\hline & \multicolumn{12}{|c|}{ EBITDA / Total assets } \\
\hline & \multicolumn{4}{|c|}{ Private equity } & \multicolumn{4}{|c|}{ B\&B Platforms } & \multicolumn{4}{|c|}{ B\&B Add-ons } \\
\hline & $\begin{array}{l}\text { TO/TA } \\
\text { growth }\end{array}$ & $\begin{array}{l}\text { TO/TA } \\
\text { decrease }\end{array}$ & $\begin{array}{l}\text { Debt/TA } \\
\text { growth }\end{array}$ & $\begin{array}{l}\text { Debt /TA } \\
\text { decrease }\end{array}$ & $\begin{array}{l}\text { TO/TA } \\
\text { growth }\end{array}$ & $\begin{array}{l}\text { TO/TA } \\
\text { decrease }\end{array}$ & \begin{tabular}{|l|} 
Debt/TA \\
growth
\end{tabular} & $\begin{array}{l}\text { Debt /TA } \\
\text { decrease }\end{array}$ & $\begin{array}{l}\text { TO/TA } \\
\text { growth }\end{array}$ & $\begin{array}{l}\text { TO/TA } \\
\text { decrease }\end{array}$ & \begin{tabular}{|l|} 
Debt/TA \\
growth
\end{tabular} & $\begin{array}{l}\text { Debt /TA } \\
\text { decrease }\end{array}$ \\
\hline Trans x Post & $0.012^{\star \star \star}$ & -0.007 & $-0.016^{\star \star \star}$ & $0.014^{\star \star \star}$ & $0.030 * \star \star$ & $-0.054^{\star \star \star}$ & 0.001 & 0.008 & $0.024^{*}$ & -0.006 & $-0.026 * \star$ & $0.035^{\star *}$ \\
\hline Post & $-0.006^{\star}$ & -0.001 & -0.003 & -0.006 & -0.002 & $0.026^{\star \star \star}$ & 0.003 & 0.008 & $-0.033^{\star \star \star}$ & -0.009 & -0.007 & $-0.026^{\star \star}$ \\
\hline Year, Firm FE & yes & yes & yes & yes & yes & yes & yes & yes & yes & yes & yes & yes \\
\hline Constant & yes & yes & yes & yes & yes & yes & yes & yes & yes & yes & yes & yes \\
\hline $\mathrm{R}^{2}$ & 0.004 & 0.01 & 0.011 & 0.005 & 0.026 & 0.023 & 0.014 & 0.023 & 0.016 & 0.012 & 0.015 & 0.025 \\
\hline No. observ. & 10174 & 9101 & 11658 & 7774 & 1762 & 1578 & 2349 & 995 & 1617 & 2750 & 2381 & 1896 \\
\hline
\end{tabular}

